\title{
The role and impact of comparison websites on the consumer search process in the US and German airline markets
}

\author{
Christopher P. Holland ${ }^{1,2} \cdot$ Julia A. Jacobs ${ }^{2}$. \\ Stefan Klein ${ }^{2}$
}

Received: 26 January 2015/Revised: 3 November 2015/Accepted: 8 November 2015/

Published online: 4 January 2016

(C) The Author(s) 2015. This article is published with open access at Springerlink.com

\begin{abstract}
The paper examines how consumers search for airline tickets based on a comparative analysis of the US and German markets. Data from comScore is analysed using an innovative application of set theory. ComScore is a leading commercial provider of business intelligence and consumer analytics based on its worldwide panel of two million online users. The search process is modelled using the concept of the consideration set based on primary search with the airline websites and secondly by the use of online travel agents and meta-search engines, which are termed comparison websites. Three generic search models are proposed: (1) primary search with airline websites only; (2) search of comparison websites only; (3) a combination of primary search and comparison websites. Each generic search model accounts for a significant proportion of overall users in both markets. The consideration sets are 2.58 in Germany and 2.74 in the United States. It is shown that the use of comparison websites significantly increases the propensity to conduct additional primary search based on analysis of all major airline pairs in both markets. The theoretical and managerial implications of the results are described and future research opportunities are outlined.
\end{abstract}

Keywords Consumer search behaviour - Online travel agents · Meta-search engines $\cdot$ Airline $\cdot$ Panel data $\cdot$ International analysis

Julia A. Jacobs

julia.jacobs@uni-muenster.de

Christopher P. Holland

chris.holland@mbs.ac.uk

Stefan Klein

stefan.klein@uni-muenster.de

1 Manchester Business School, University of Manchester, Booth Street West,

Manchester M15 6PB, UK

2 Department of Information Systems, University of Münster, Leonardo Campus 11, 48149 Muenster, Germany 


\section{Introduction}

Online travel agents (OTAs) are powerful companies in the airline and travel markets where the market leaders Expedia and Priceline account for gross bookings of $\$ 50.4$ billion and $\$ 50.3$ billion respectively (Expedia 2015; Priceline 2015). These companies play a crucial role in the online search process for all forms of travel planning (Xiang et al. 2015). One of the key features of an OTA in the airline market is a compilation and comparison of competing offers that meet the consumer's requirements in terms of their choice criteria such as origin-destination and date of travel, and a comparison of available offers. OTAs therefore facilitate the consumer search process by offering a fast and efficient method for consumers to search and evaluate a range of competing offers, that is, they support multicriteria decision making and provide market transparency (Buhalis and Licata 2002). OTAs are therefore economically and strategically prominent intermediaries in the global travel market.

In this paper, the term online travel agent, e.g. Expedia, refers to a website that offers search across airlines, price comparison and booking functionality. In addition, there are meta-search engines such as Kayak, which also offer price comparison but without booking capability. The focus of this paper is on the influence of comparison functionality, whether this is done through an OTA or a meta-search engine, on direct search with airline websites. We therefore use the term comparison website to include both OTAs and meta-search engines. We also distinguish between OTAs and meta-search engines for specific examples.

The travel industry has been at the forefront of online search and booking, and has an established and well-documented history of technology innovation and disruption of distribution systems going back to Computerized Reservation Systems (CRSs) (Inkpen 1998). The airlines have also invested heavily into online marketing and distribution so that consumers can search and book flights online, and also buy related travel services such as hotels, car hire and holiday packages, directly from an individual airline. Given numerous constraints of fleet management in a complex network, an airline's seat capacity on any single connection is fixed in the short term. Airlines respond with dynamic pricing and extensive yield management in order to maximize revenues.

An airline ticket constitutes a personalized contract specifying the carrier (i.e. airline offering the service), an origin-destination pair, a time and date of travel, a service bundle (e.g. piece and weight of luggage, seat selection, food and entertainment) and price. These characteristics are important because they make it possible to compare offers from competing airlines based on a small set of key criteria. From a consumer marketing perspective, online research is a crucial part of the customer journey and it is reasonable to assume that consumers would tend to conduct extensive search processes in order to find suitable flights, and to minimize the price. 
The focus of this research is to empirically study the search process using an innovative application of set theory, which allows us to distinguish between: (1) direct search on the airline websites; (2) use of comparison websites; and (3) analyse the interaction effects between (1) and (2). The US and German markets were chosen because of their size and sophistication. The US is the largest airline market worldwide and has a highly developed online market. Germany is the 5th largest airline market in the world and is the largest online market in Europe (Pearce 2014). These two markets are therefore very good indicators of advanced online search behaviour in airline markets.

The structure of the paper is as follows. A literature review of the search process is presented that is organised around the themes of the consideration set and previous research into OTAs and meta-search engines. A research framework is proposed that integrates direct search with the use of comparison websites. An explanation of the innovative methodology that uses set theory to analyse online panel data is given and the results for the US and German markets are presented. A discussion of the results and limitations of the study are given, and the managerial implications of the results are described. Finally the conclusions and the theoretical contribution of the study are presented.

\section{Literature review}

Our literature review covers (a) the construct of the 'consideration set' and (b) studies of comparison websites.

\subsection{The consideration set}

Even though the consideration set is an important concept in marketing (Brown and Wildt 1992), it has received relatively limited empirical attention during the preInternet era. Hauser and Wernerfelt (1990) conducted an authoritative survey and found only ten papers that covered 23 product categories in total. The consideration set is an established and widely used marketing concept that has been documented since the 1960s (Howard 1963, 1977; Howard and Sheth 1969). Howard (1963) and Howard and Sheth (1969) referred to the set of brands considered when contemplating a purchase within a particular product class, the number of brands a buyer considers when contemplating a purchase and the notion of acceptable brands considered in a purchasing decision. Howard (1977) formally introduced the term 'evoked set', and defined it as:

the subset of brands that a consumer would consider buying out of the set of brands in the product class of which he or she is aware

(Howard 1977, p. 32).

Roberts (1989) refers to Howard's (1963) definition. Hauser et al. (1983) used the term 'consideration set' in place of evoked set, though the definitions are equivalent. Hauser and Wernerfelt (1990, p. 393) gave a precise definition of the consideration set: 
The theoretical construct of a consideration set is those brands that the consumer considers seriously when making a purchase and/or consumption decision.

Although there are differences in emphasis, the concept of the consideration set and the earlier equivalent term of 'evoked set', has remained broadly the same over the past 50 years. It is the group of brands that a consumer actively considers when making a purchasing decision. The pre-requisites of being included in the consideration set are that a consumer must be aware of the brand and also judge it to be acceptable, at least for consideration and evaluation.

The formation and evaluation of the consideration set are clearly important features in the customer journey. At the start of the customer journey there is the universal set of brands within a particular market. For an individual consumer, this is immediately reduced to the awareness set, from which the consumer selects a set of brands, which she regards as worthy of active consideration (Shocker et al. 1991). The shape of the journey measured by the number of brands has been conceptualized as a funnel that starts with the widest possible set of options and ends in an individual making a purchase. The choice of a particular brand from the consideration set involves consumer search and evaluation, including the acquisition and evaluation of information from multiple sources. The customer journey metaphor in which the universal set is reduced to a single purchased brand is an apt metaphor, and the concept of a sales funnel captures to an extent, the shape of the journey measured by the inclusion and exclusion of competing brands. We consider competing brands to be provider brands, i.e. airline brands in the airtravel market and not meta-search or OTA brands. In this way, the intermediaries are not used for the calculation of the consideration set.

There are very few empirical studies that apply the consideration set in an online context and measure the nature and extent of the online search process to evaluate competing brands. Johnson et al. (2004) measured the consideration set size for a range of consumer markets in the US and reported very narrow search results of 1.2 (books), 1.3 (CDs) and 1.8 (air travel sites), meaning that consumer visited on average 1.2, 1.3 and 1.8 websites respectively. Their sample of air travel websites consisted of a combination of both OTAs (Expedia, Travelocity) and also airline websites. Zhang et al. (2006) repeated Johnsońs work a couple of years later and found similar results: 2.1 (CDs), 3.3 (airline tickets), 3.3 (computer hardware). A McKinsey study on the financial services sector in Germany reported a higher consideration set of 3.8 (Meyer and Stobbe 2010). Holland and Mandry (2013) conducted an international, cross-sector analysis of banking, grocery, airlines, telecommunications, insurance and automotive. They reported consideration set sizes ranging from 2.40 to 2.77 in the UK and 2.13-2.60 in the United States. The method used in all of these studies is to measure the consideration set based on the number of brands included in the search process, indicated by the range of different websites visited. In the airline market this is the number of airline websites visited.

In summary, the few empirical results show that the average online consideration set size is relatively small. This is contrary to economic and marketing theories that predict extensive search patterns based on very low search costs using the Internet (Stigler 1961; Jepsen 2007; Bucklin and Sismeiro 2009). This raises an important question. Why is the average online consideration set relatively small, i.e. why do 
consumers not engage in more extensive search-patterns? One possible explanation is that consumers use OTAs and meta-search engines to assess the market. It is therefore necessary to consider search behaviour that includes comparison websites (whether this is on an OTA or a meta-search engine) in addition to direct search with airline websites.

\subsection{Comparison websites}

The Internet and online intermediaries improve access to information and dramatically lower search costs (Laffey and Gandy 2009; Dickinger and Stangl 2012; Lee et al. 2007). However, there remains significant price and product dispersion in the travel market, which indicates that an intensive search process is worthwhile (Baye et al. 2003). Table 1 shows an overview of the key literature on comparison web sites.

In the airline industry, Collins et al. (2010) demonstrate significant heterogeneity of search preferences, which implies that the effects of the Internet and comparison websites on search behaviour will be uneven (Dickinger and Stangl 2012). In the hotel market, Anderson (2011) used panel data to explore the interaction between a hotel price comparison website and direct research with individual hotels, and found that $75 \%$ of travellers used the comparison engine in combination with direct search. As there appears to be no research that models the interaction between direct search and the use of comparison websites using the online consideration set concept, we are suggesting a research design for exploring this problem, which is elaborated in the next section.

\section{Research framework and hypotheses}

Based on empirical search patterns, three generic search patterns that are shown diagrammatically in Fig. 1, define the online customer search process and which we are using hereafter. Model 1 and 2 have been constructed based on a simple logical search process of consumers. The interconnection of the market players can be seen in model 3 and has been similarly shown by other authors (Werthner and Klein 1999; Xiang and Gretzel 2010).

In model 1, consumers search airline websites only. In model 2 , consumers only investigate comparison websites. In model 3, consumers combine search of comparison websites and airline websites. The consideration set concept is only applied to the primary search with airline websites, whether this is done on its own as in model 1, or in conjunction with comparison websites as shown in model 3. This is based on the definition of the consideration set (Hauser and Wernerfelt 1990), which means the number of airline brands considered. This definition excludes comparison websites because an OTA or meta-search engine is a source of information regarding airline travel and is not an airline brand.

Hypothesis 1: The online consideration set based on primary search with airline websites only will be in the region of 2.5-3.0 based on the earlier results from 
Table 1 Literature overview on comparison websites

\begin{tabular}{|c|c|c|c|c|}
\hline Author and year & Theory focus & Methodology & Product type & Nature of the sample data \\
\hline $\begin{array}{l}\text { Baye et al. } \\
\text { (2003) }\end{array}$ & Price dispersion & $\begin{array}{r}\text { Online data } \\
\text { collection }\end{array}$ & $\begin{array}{r}\text { Electronic } \\
\text { products }\end{array}$ & $\begin{array}{l}1 \text { price comparison }(\mathrm{PC}) \text {, } \\
\text { Shopper.com }\end{array}$ \\
\hline $\begin{array}{c}\text { Kamakura and } \\
\text { Moon (2009) }\end{array}$ & $\begin{array}{l}\text { Price efficiency } \\
\text { and quality of } \\
\text { products }\end{array}$ & $\begin{array}{l}\text { Hedonic } \\
\text { regression }\end{array}$ & Airline & $\begin{array}{l}3 \text { OTAs, Expedia, Orbitz, } \\
\text { Travelocity }\end{array}$ \\
\hline Bilotkach (2010) & $\begin{array}{l}\text { Economic } \\
\text { pricing models }\end{array}$ & $\begin{array}{r}\text { Online data } \\
\text { collection }\end{array}$ & Travel & 1 Airline, 1 OTA (Orbitz) \\
\hline $\begin{array}{l}\text { McDonald and } \\
\text { Wren (2012) }\end{array}$ & $\begin{array}{l}\text { Advertising } \\
\text { effectiveness } \\
\text { and price } \\
\text { strategies }\end{array}$ & $\begin{array}{r}\text { Online data } \\
\text { collection }\end{array}$ & Insurance & $1 \mathrm{PC}$, Confused.com \\
\hline $\begin{array}{l}\text { Law et al. } \\
\quad(2010)\end{array}$ & $\begin{array}{l}\text { Information and } \\
\text { price display }\end{array}$ & $\begin{array}{r}\text { Online data } \\
\text { collection }\end{array}$ & Airline & $\begin{array}{l}5 \text { OTAs, Cheaptickets, } \\
\text { Expedia, Orbitz, } \\
\text { Travelocity, Zuji }\end{array}$ \\
\hline $\begin{array}{l}\text { Laffey and } \\
\text { Gandy (2009) }\end{array}$ & $\begin{array}{l}\text { Relation between } \\
\text { price } \\
\text { comparison } \\
\text { and purchase }\end{array}$ & Case study & Financial services & $\begin{array}{l}3 \text { PC, uswitch, } \\
\text { moneyfacts, moneynet }\end{array}$ \\
\hline $\begin{array}{l}\text { Jung et al. } \\
\text { (2014) }\end{array}$ & $\begin{array}{l}\text { Product type, } \\
\text { price and value } \\
\text { perceptions }\end{array}$ & $\begin{array}{l}\text { Laboratory } \\
\text { experiment }\end{array}$ & Notebook, jeans & $1 \mathrm{PC}$ \\
\hline Chung (2013) & $\begin{array}{l}\text { Intermediaries } \\
\text { and price } \\
\text { dispersion }\end{array}$ & Survey & Digital cameras & $1 \mathrm{PC}$ \\
\hline $\begin{array}{l}\text { Christodoulidou } \\
\text { et al. (2010) }\end{array}$ & $\begin{array}{l}\text { Examination of } \\
\text { the } \\
\text { intermediaries } \\
\text { role with the } \\
\text { suppliers }\end{array}$ & Case study & Travel & $\begin{array}{l}2 \text { OTAs, } 2 \text { PCs } \\
\text { (confidential) }\end{array}$ \\
\hline $\begin{array}{l}\text { Kracht and } \\
\text { Wang (2010) }\end{array}$ & $\begin{array}{l}\text { Evolution of the } \\
\text { tourism } \\
\text { distribution } \\
\text { channel }\end{array}$ & $\begin{array}{l}\text { Theoretical } \\
\text { general } \\
\text { review }\end{array}$ & Travel & Intermediaries \\
\hline Tan et al. (2010) & $\begin{array}{l}\text { Search cost, } \\
\text { market } \\
\text { structure and } \\
\text { performance }\end{array}$ & $\begin{array}{l}\text { Laboratory } \\
\text { experiment }\end{array}$ & $\mathrm{n} / \mathrm{A}$ & $\begin{array}{l}1 \text { comparison shopping, } \\
168 \text { students }\end{array}$ \\
\hline $\begin{array}{l}\text { Chatterjee and } \\
\text { Wang (2012) }\end{array}$ & $\begin{array}{l}\text { Search } \\
\text { dispersion and } \\
\text { duration } \\
\text { related to } \\
\text { purchases }\end{array}$ & $\begin{array}{l}\text { Online panel } \\
\text { data and } \\
\text { clickstream } \\
\text { analysis }\end{array}$ & Travel & $\begin{array}{l}\text { Panel size: } 50,000 \text { from } \\
\text { comScore, range of PC } \\
\text { and OTAs }\end{array}$ \\
\hline Janger (2010) & $\begin{array}{l}\text { Price } \\
\text { comparison, } \\
\text { search and } \\
\text { switching rates }\end{array}$ & Survey & $\begin{array}{l}\text { Banking, } \\
\text { insurance, trades, } \\
\text { food, motor } \\
\text { fuels, electric } \\
\text { products }\end{array}$ & $\begin{array}{l}2000 \text { respondents, details } \\
\text { of PC/OTA not stated }\end{array}$ \\
\hline $\begin{array}{l}\text { Collins et al. } \\
\text { (2010) }\end{array}$ & $\begin{array}{l}\text { Search and } \\
\text { choice }\end{array}$ & Survey & Airline & 462 respondents, 1 OTA \\
\hline
\end{tabular}


Table 1 continued

\begin{tabular}{|c|c|c|c|c|}
\hline Author and year & Theory focus & Methodology & Product type & Nature of the sample data \\
\hline Anderson (2011) & $\begin{array}{l}\text { Search process } \\
\text { and its } \\
\text { relationship to } \\
\text { online sales }\end{array}$ & $\begin{array}{l}\text { Online panel } \\
\text { data and } \\
\text { clickstream } \\
\text { analysis }\end{array}$ & Hotel & $\begin{array}{l}1720 \text { hotel reservations, } \\
\text { based on comScore data } \\
1 \text { OTA Expedia }\end{array}$ \\
\hline $\begin{array}{l}\text { Breuer et al. } \\
\text { (2011) }\end{array}$ & $\begin{array}{l}\text { Advertising } \\
\text { effectiveness } \\
\text { and consumer } \\
\text { behaviour }\end{array}$ & $\begin{array}{l}\text { Ecommerce } \\
\text { data from a } \\
\text { single } \\
\text { company }\end{array}$ & Books & $\begin{array}{l}2.8 \text { million purchases, } 1 \\
\text { PC }\end{array}$ \\
\hline $\begin{array}{l}\text { Robertshaw } \\
\text { (2011) }\end{array}$ & $\begin{array}{l}\text { Customer } \\
\text { acquisition and } \\
\text { retention }\end{array}$ & Theory & Insurance & $\begin{array}{l}4 \text { PC (GoCompare, } \\
\text { Confused, } \\
\text { Moneysupermarket, } \\
\text { Compare the market), } 1 \\
\text { insurance brand }\end{array}$ \\
\hline
\end{tabular}

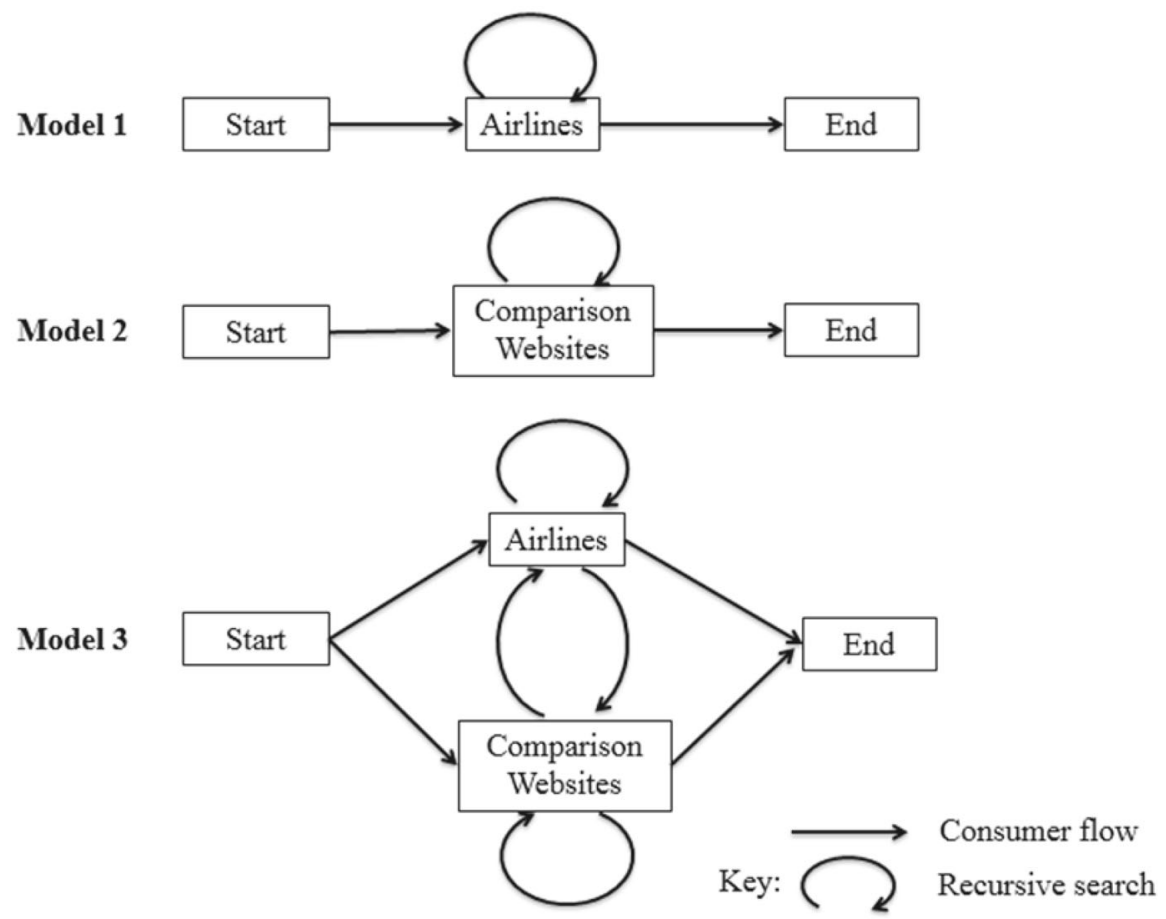

Fig. 1 Generic online search models for airline flights

Johnson et al. (2004), Zhang et al. (2006), Holland and Mandry (2013), and Holland and Jacobs (2015).

This range is relatively small compared to the pre-Internet results from Hauser and Wernerfelt (1990), which reported an average of 3.98 from the assessor 
database research project and 4.05 based on nine separate studies. The extent of the search process is an indication of the level of competitive intensity within a market. The implicit theoretical assumption of the electronic markets hypothesis is that the Internet increases the breadth of search (Bakos 1998) whereas the few empirical studies that have attempted to measure the online consideration set in a systematic manner have reported significantly lower results than might reasonably be expected. The range of 2.5-3.0 is given based on the bounds of previous online studies, and is substantially lower than the results reported by Hauser and Wernerfelt (1990).

Hypothesis 2: The majority of consumers will use comparison websites, i.e. an OTA or a meta-search engine, as part of their search process. This includes both Model 2 and Model 3 search behaviour.

The US and Germany are both highly advanced online markets and therefore one would expect sophisticated search behaviour. The logic is that comparison websites help users achieve an extensive search process in an efficient manner. The other evidence to support this hypothesis is the economic size of the leading OTAs such as Expedia and Priceline, and their very high numbers of online users (Xiang et al. 2015).

Hypothesis 3: The use of comparison websites is a substitute for extensive direct research with airline websites. It is therefore expected that these users will have a lower propensity to conduct further search with a second airline website compared with users that do not use conduct comparisons through an OTA or meta-search engine.

The theoretical logic is that consumers will continue to search until the cost of additional search outweighs the expected benefits (Stigler 1961). It is therefore surprising that most consumers do not conduct an extensive search process of the airline websites. A plausible explanation for this behaviour is that consumers are using OTAs and meta-search engines to give them coverage of the market instead of conducting extensive direct search with different individual airline websites. There are no previous empirical research results that specifically address the interaction between comparison websites and direct search and this is therefore an important question to address.

\section{Methodology}

\subsection{Clickstream data}

Online panel data uses clickstream data from a large panel of online users that is generated as they surf across different websites (Bucklin and Sismeiro 2009). ComScore is a world leader in online digital analytics and their research data has been used in previous research (Lohse et al. 2000; Johnson et al. 2004; Zhang et al. 2006). It has also been used to analyse online consideration sets (Holland and Mandry 2013; Holland and Jacobs 2015). ComScore is a powerful source of information because it provides massive scale, international scope, very detailed 
granularity and the ability to measure surfing patterns of very large groups of individuals across multiple websites. Its worldwide online panel is approximately two million users. See comScore (2014) for a commercial overview of their business model.

\subsection{Measurement of the online consideration set}

The consideration set is defined as the number of airline website brands visited. Note that it is not possible to track search behaviour within an individual website using standard panel data reports. There is therefore a trade-off between more extensive information about search behaviour across multiple websites by using online panel data and more detail about specific search paths within websites based on web server data. In the context of research into the search process during a customer journey it is clearly much more useful to use data that covers the journey rather than have very detailed information about a single stage of the journey. Two limitations follow from this approach: (1) it is not possible to analyse the detailed search within an individual airline website to see which and how many flights (including code-sharing offers for airline alliances) are evaluated; (2) we do not know what happens within a comparison website, in particular the number of brands considered. The comparison websites are therefore modelled to focus on the overall search process, the interaction between airline websites and comparison websites, and the consideration set of airline brands.

The audience duplication report gives the total number of visitors to a set of airlines, the number that visit one airline only and the number that visit two or more airlines within a month, i.e. the report gives us insights into search for multiple airline brands. An assumption is made that customers visiting one website only are more likely to be conducting some form of e-service rather than actively searching for a flight and are excluded from the online consideration set calculation. The authors are aware that there may be a number of false negatives: e.g. travellers searching for flights just on the Lufthansa website, which includes Lufthansa's code share partners, but do not have a way of identifying them at this time. Those customers that visit two or more websites are regarded as active searchers. This approach to measuring the online consideration set is consistent with the marketing definition and use of the term consideration set (Brown and Wildt 1992). The online consideration set is calculated by: (a) summing the number of different airline websites visited by all searchers; and (b) dividing by the number of searchers (Zhang et al. 2006).

\subsection{Distribution of users across the generic online search models 1,2 and 3}

Audience duplication reports of the airlines and the comparison websites were used to calculate the distribution of users across the search models as shown in Fig. 2. $\alpha$ refers to the set of all major airlines in the market, \{airline 1, airline 2, airline 3 ... airline $n$ \}. $\beta$ refers to the set of all of the major comparison websites, \{agent 1 , agent 2 , agent $3 \ldots$ agent $n\} . \alpha, \beta$ and $(\alpha \cup \beta)$ are calculated based on the comScore audience duplication reports for (i) all airlines, (ii) all comparison websites, and (iii) all airlines and comparison websites. 
Visitors to Airline Websites, $\alpha$ Visitors to Comparison Websites, $\beta$

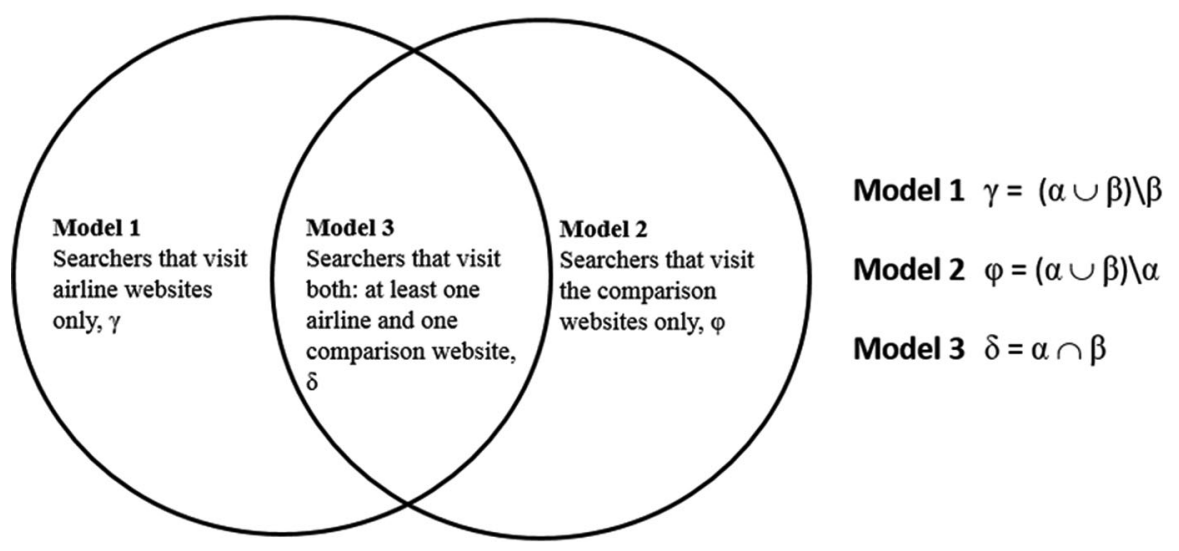

Fig. 2 The calculation of visitors to each of the generic search models

\subsection{Calculating the probability of additional search}

Three websites are shown in Fig. 3: Airlines 1 and 2 and an online travel agent. Sets A to $\mathrm{G}$ can be calculated directly from the intersections of the two airlines and the travel agent website. $\mathrm{X} \cap \mathrm{Y} \cap \mathrm{Z}$ is given empirically in the audience duplication report for $\{X, Y, Z\}$. Similarly, $(X \cap Y),(X \cap Z)$ and $(Y \cap Z)$ are given empirically in the three separate audience duplication reports for $\{X, Y\},\{X, Z\}$ and $\{Y, Z\}$.

The customers of Airline $1(\mathrm{X})$ are divided into two groups: those that don't use the online travel agent website (Group 1), and those that use the online travel agent

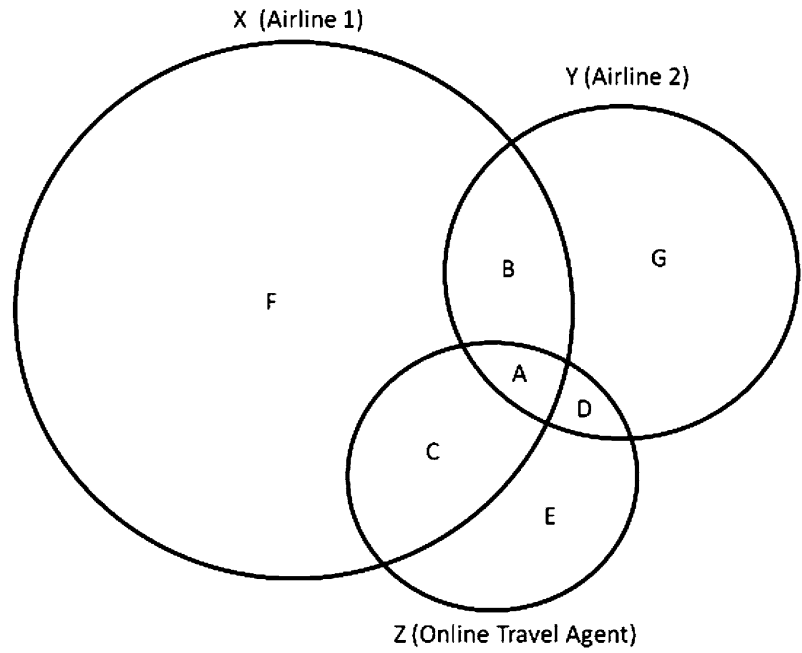

$$
\begin{aligned}
& A=X \cap Y \cap Z \\
& B=(X \cap Y) \backslash A \\
& C=(X \cap Z) \backslash A \\
& D=(Y \cap Z) \backslash A \\
& E=Z \backslash(A \cup C \cup D) \\
& F=X \backslash(A \cup B \cup C) \\
& G=Y \backslash(A \cup B \cup D)
\end{aligned}
$$

Fig. 3 The visiting patterns to two airlines and an online travel agent 
website (Group 2). Based on the panel data, the probability of the customers in each group of visiting the second airline can then be calculated as follows. The probability of additional search for a sample of airline pairs and a comparison website are calculated for a sample within each market in the form of a natural experiment (Campbell and Stanley 1963; Neslin and Shoemaker 1983).

\subsubsection{Airline 1 Customers}

Group 1 Customers of Airline 1 that don't use the online travel agent website is given by $(\mathrm{B} \cup \mathrm{F})$. The probability of Group 1 visiting Airline $2=\frac{B}{B \cup F}$.

Group 2 Customers of Airline 1 that use the online travel agent website is given by $(\mathrm{A} \cup \mathrm{C})$. The probability of Group 2 visiting Airline $2=\frac{A}{A \cup C}$.

\subsubsection{Airline 2 Customers}

Group 1 Customers of Airline 2 that don't use the online travel agent website is given by $(B \cup \mathrm{G})$. The probability of Group 1 visiting Airline $1=\frac{B}{B \cup G}$.

Group 2 Customers of Airline 2 that use the online travel agent website is given by $(\mathrm{A} \cup \mathrm{D})$. The probability of Group 2 visiting Airline $1=\frac{A}{A \cup D}$.

\section{Analysis and results}

All figures for the German and US market are retrieved from comScore reports for the time period of 1 month, in this case May 2014. Total airline visitors is the number of consumers that look at any airline website. If an individual visits two or more airline websites, they are only counted once. This is the number of unduplicated, unique visitors in the sample. The total number is divided into two categories, those that look at one website only (e-service), and those that look at two or more websites (searchers).

\subsection{Hypothesis 1}

The unique visitor results for Germany and the US are shown in Tables 2, 3, 4 and 5.

It can be seen in Tables 2 and 4 that the individual airlines attract large numbers of online users. The first stage of the analysis is to measure the breadth (extent) of the primary research. That is, the online consideration set is based on direct visits to individual airline websites only, regardless of whether or not users visit a comparison website. The results for both markets are shown in Table 6.

The total airline website visitors is the number of consumers looking at any of the airline websites. Note that this is smaller than the sum of the unique visitors to each airline shown in Table 2 (6048) because some visitors go to more than one airline website. The figure of 6048 is the total number of visits made to different websites by all online users. The total airline visitors of 4240 are divided into two groups: e-service and search. 
Table 2 Airlines, Germany

Sources: Audience duplication reports, Germany and United States, ComScore

Table 3 Comparison websites, Germany

Sources: Audience duplication reports, Germany and United States, ComScore

\begin{tabular}{lc}
\hline Airlines & Unique visitors (000s) \\
\hline AIRBERLIN.COM & 1057 \\
LUFTHANSA.COM & 956 \\
GERMANWINGS.COM & 924 \\
RYANAIR.COM & 729 \\
TUIFLY.COM & 492 \\
CONDOR.COM & 423 \\
EASYJET.COM & 282 \\
WIZZAIR.COM & 241 \\
TURKISHAIRLINES.COM & 162 \\
BRITISHAIRWAYS.COM & 150 \\
EMIRATES.COM & 123 \\
SWISS.COM & 98 \\
KLM.COM & 95 \\
VUELING.COM & 91 \\
FLYPGS.COM & 87 \\
AUSTRIAN.COM & 60 \\
IBERIA.COM & 45 \\
QATARAIRWAYS.COM & 33 \\
\hline
\end{tabular}

\begin{tabular}{ll}
\hline Comparison websites & Unique visitors (000s) \\
\hline FLUEGE.DE & 2241 \\
EXPEDIA.DE & 1524 \\
BILLIGFLUEGE.DE & 1260 \\
OPODO.DE & 1236 \\
KAYAK.DE & 315 \\
SKYSCANNER.DE & 273 \\
FLUG24.DE & 231 \\
SKYCHECK.COM & 145 \\
\hline
\end{tabular}

The number of airline websites visited by searchers is calculated by subtracting the e-service consumers from the total number of visits made by all online users, i.e. $6048-3092=2956$ because by definition e-service customers only visit one airline brand. In Germany, the total number of websites visited by the searchers (2956) is divided by the number of searchers (1148), which equals a consideration set of 2.58 .

The online consideration sets for Germany and the US are similar and fall within the range of 2.5-3.0. Hypothesis 1 is therefore accepted. This means that consumers in both markets look at just 2 or 3 airline websites on average, with very few conducting a more extensive search process. This is a striking result given that there are 18 major airlines operating in Germany and also 18 in the United States. 
Table 4 Airlines, US

\begin{tabular}{ll}
\hline Airlines & Unique visitors (000s) \\
\hline SOUTHWEST.COM & 7846 \\
DELTA.COM & 5058 \\
AA.COM & 4557 \\
UNITED.COM & 4234 \\
AIRNEWZEALAND.COM & 2967 \\
USAIRWAYS.COM & 2607 \\
JETBLUE.COM & 2317 \\
ALASKAAIRLINES.COM & 1329 \\
SPIRIT.COM & 1234 \\
FLYFRONTIER.COM & 1002 \\
ALLEGIANTAIR.COM & 866 \\
VIRGINAMERICA.COM & 827 \\
AIRTRAN.COM & 737 \\
HAWAIIANAIR.COM & 514 \\
EMIRATES.COM & 407 \\
BRITISHAIRWAYS.COM & 330 \\
AIRCANADA.COM & 284 \\
LUFTHANSA.COM & 225 \\
AIRFRANCE.US & 158 \\
\hline
\end{tabular}

Sources: Audience duplication reports, Germany and United States, ComScore

Table 5 Comparison websites, US

\begin{tabular}{llc}
\cline { 2 - 2 } Table 5 Comparison websites, & Comparison websites & Unique visitors (000s) \\
\cline { 2 - 3 } & EXPEDIA.COM & 12,146 \\
& PRICELINE.COM & 8834 \\
& TRAVELOCITY.COM & 6469 \\
& FINDTHEBEST.COM & 5867 \\
& CHEAPOAIR.COM & 5696 \\
& ORBITZ.COM & 4989 \\
& KAYAK.COM & 4602 \\
& HOTWIRE.COM & 3227 \\
& TRAVELZOO.COM & 2626 \\
& ONETRAVEL.COM & 1999 \\
Sources: Audience duplication & CHEAPTICKETS.COM & 1933 \\
reports, Germany and United & BOOKINGBUDDY.COM & 1911 \\
States, ComScore & &
\end{tabular}

Sources: Audience duplication reports, Germany and United States, ComScore

\subsection{Hypothesis 2}

The comparison websites are significantly larger than the airline companies in both markets, measured by unique visitors. It is therefore important to understand the generic online search models as shown in Figs. 1 and 2 in order to gain an overview of online consumer search behaviour. The results are shown in Table 7. 
Table 6 General search model results for Germany and US

\begin{tabular}{lll}
\hline Measurement & \multicolumn{2}{l}{ Unique visitors (000s) } \\
\cline { 3 - 3 } & Germany & United States \\
\hline Total airline website visitors & 4240 & 25,123 \\
E-service customers, i.e. visit one airline website only & $3092(73 \%)$ & $18,019(72 \%)$ \\
Searchers, i.e. visit two or more airline websites & $1148(27 \%)$ & $7104(28 \%)$ \\
Number of airline websites visited by searchers & 2956 & 19,479 \\
Online consideration set (OCS) & 2.58 & 2.74 \\
\hline
\end{tabular}

The OCS is not displayed in 000s. The figure shows the average number of different airline websites, i.e. airline brands, visited

Table 7 Generic online search model results: see Fig. 2

\begin{tabular}{lll}
\hline Measurement & \multicolumn{2}{l}{ Unique visitors (000s) } \\
\cline { 2 - 3 } & Germany & United States \\
\hline Unduplicated visitors to all airlines (set $\alpha$ in Fig. 2) & 4240 & 25,123 \\
Unduplicated visitors to all comparison websites (set $\beta$ in Fig. 2) & 3878 & 32,360 \\
Unduplicated visitors to the airlines and comparison websites $(\alpha \cup \beta)$ & 6491 & 44,191 \\
Model 1 Airlines only (set $\gamma$ in Fig. 2) & $2613(40 \%)$ & $11,831(27 \%)$ \\
Model 2 Comparison websites only (set $\varphi$ in Fig. 2) & $2251(35 \%)$ & $19,068(43 \%)$ \\
Model 3 Combination of airlines and comparison websites (set $\delta$ in & $1627(25 \%)$ & $13,292(30 \%)$ \\
Fig. 2) & &
\end{tabular}

The unduplicated visitors to all airlines is the total number of individuals that visited one or more of the airline websites within the time period of 1 month, in this case May 2014. The definition of unduplicated visitors to all of the comparison websites is the same. Based on the empirical results from the three unduplicated visitor reports, the distribution of searchers across the three search models is calculated, as shown in Fig. 2.

The importance of comparison websites is demonstrated by the sum of Model 2 and Model 3 users, which gives the percentage of all users that visit a comparison website, either in conjunction with primary search (Model 3), or visiting comparison websites only (Model 2). In Germany $60 \%$ (35 and $25 \%$ ) of the total user group in this sample visit comparison websites and in the US the figure is higher at $73 \%$ (43 and $30 \%$ ). Hypothesis 2 is therefore accepted.

These results also mean that in Germany, $40 \%$ of users only visit airline websites, and in the US, this number is only $27 \%$. This means that there are two distinctive groups of online users that visit airline websites: those that don't use comparison websites, and those that do use comparison websites. This presents an opportunity to analyse the generic search models to test Hypothesis 3 by comparing the search behaviour of these two groups in more detail. 
The specific research objective is to test whether comparison websites act as a substitute for primary search with airline websites, stimulate primary search, or have no discernible effect. This is a crucial question because a plausible explanation for small online consideration sets is that consumers use OTAs or meta-search engines, which have comparison functionality, rather than conduct their own search directly with individual airline websites. On the face of it, this seems a rational search strategy. However the actual effect of comparison websites on primary search has not been tested in previous research and online panel data provides an ideal opportunity to conduct what is a natural experiment on a very large sample of online users (Meyer 1995; Chen et al. 2011; McLeod 2012).

\subsection{Hypothesis 3}

The purpose of this hypothesis is to test the effect of the use of comparison websites on the propensity to conduct additional primary search. A sample of the largest airline pairs in Germany and the United States was taken in order to investigate the propensity to search for a further airline within this group. In order to test the interaction of searchers with airlines and comparison websites, the following OTAs with the largest number of visitors were selected for each country: Fluege.de (Germany) and Expedia.com (US), see Tables 3 and 5 for further details. The set analysis used to calculate the results is shown in Fig. 3. The empirical results for Germany are shown in Table 8 and those for the United States are shown in Table 9.

Note that Group 1 members only conduct primary search and are Model 1 type users. Group 2 conduct primary search and also visit comparison websites, and are Model 3 type users (see Figs. 1, 2). This analysis therefore applies to $65 \%$ of the German market and $57 \%$ of the US market. The remainder in both markets only visit comparison websites and the question of the effect of the comparison website on primary search is not applicable.

The probabilities shown for Groups 1 and 2 represent the probability for a user of the airline in column 1 also visiting the airline shown in column 2 , within the sampling period of 1 month. For each airline pair in both Germany and the United States, Group 2 users are significantly more likely to conduct search in both airline websites. The third column shows the ratio of the probabilities to conduct further search for Group 2/Group 1. N.B. Similar analyses were also conducted with the OTA Opodo in Germany and the results were consistent with those shown below. The analysis was also repeated in both markets using Kayak.com, a meta-search engine, and similar results were observed.

The results in Tables 8 and 9 show a clear difference between the search behaviour of groups 1 and 2 for both markets and for every single natural experiment. It is therefore reasonable to reject the hypothesis that the use of comparison websites acts as a substitute for direct search because each experiment disconfirms this idea. Hypothesis 3 is therefore rejected. Instead the results suggest that the OTAs (Fluege and Expedia) are a catalyst for the consumer to conduct further search, which is evidenced by a substantially higher probability of visiting a 
Table 8 Probability of search with second airline for users and non-users of Fluege.de in (Germany)

\begin{tabular}{lllll}
\hline From & To & $\begin{array}{l}\text { Probability of online users of the first airline also } \\
\text { visiting the second airline in the month sample } \\
\text { period }\end{array}$ & $\begin{array}{l}\text { Ratio of } \\
\text { probabilities for } \\
\text { Group 2 to Group } \\
1^{\text {b }}\end{array}$ \\
\cline { 3 - 4 } & & $\begin{array}{l}\text { Group 1 }{ }^{\text {a }} \text { (set B in } \\
\text { Fig. 3): don't use online } \\
\text { travel agent (\%) }\end{array}$ & $\begin{array}{l}\text { Group 2 (set A in } \\
\text { Fig. 3): use online } \\
\text { travel agent (\%) }\end{array}$ & \\
\hline Airberlin & Ryanair & 2.7 & 26.7 & 9.9 \\
Airberlin & Lufthansa & 11.1 & 25.4 & 2.3 \\
Airberlin & Germanwings & 11.0 & 38.5 & 3.5 \\
Germanwings & Ryanair & 8.0 & 28.5 & 3.6 \\
Germanwings & Lufthansa & 12.0 & 35.3 & 2.9 \\
Germanwings & Airberlin & 12.7 & 43.2 & 3.4 \\
Lufthansa & Airberlin & 13.6 & 24.0 & 1.8 \\
Lufthansa & Germanwings & 12.3 & 29.6 & 2.4 \\
Lufthansa & Ryanair & 3.5 & 17.2 & 4.9 \\
Ryanair & Airberlin & 4.6 & 31.2 & 6.8 \\
Ryanair & Germanwings & 11.6 & 29.6 & 3.6 \\
Ryanair & Lufthansa & 5.3 & 17.8 & 3.4 \\
\hline
\end{tabular}

${ }^{\mathrm{a}}$ Group 1 and 2 refer to the definition used in Sect. 4.4

b This measures the scale of the effect of the use of an online travel agent on additional primary search for each pair of airlines

further airline, which will lead overall to a more extensive search process. The evidence to support this catalyst hypothesis is very strong and based on 42 separate individual experiments that use the set theory shown in Fig. 3. The US and German airline markets are both very large and highly sophisticated, and the analysis of the largest airlines and OTAs in these markets means that the results are based on very high volumes of search activity in both markets.

\section{Discussion and limitations}

These results have several important implications for search theory and management practice. Taking the airline websites separately, the consideration set is relatively small and this result is consistent with earlier studies that used online panel data to accurately measure real behaviour of very large samples of users (Holland and Mandry 2013; Zhang et al. 2006; Johnson et al. 2004). The most obvious possible explanation for a relatively narrow search pattern is that comparison websites are used in place of primary search with the airline websites but our evidence does not support this idea, and instead we conclude that comparison websites, whether this is an OTA or a meta-search engine, increase the level of direct search with airline websites. 
Table 9 Probability of searching a second airline website for users and non-users of Expedia.com (US)

\begin{tabular}{|c|c|c|c|c|}
\hline \multirow[t]{2}{*}{ From } & \multirow[t]{2}{*}{ To } & \multicolumn{2}{|c|}{$\begin{array}{l}\text { Probability of online users of the first airline } \\
\text { also visiting the second airline }\end{array}$} & \multirow{2}{*}{$\begin{array}{l}\text { Ratio of } \\
\text { probabilities } \\
\text { for Group } 2 \\
\text { to Group } 1\end{array}$} \\
\hline & & $\begin{array}{l}\text { Group 1: } \\
\text { don't use } \\
\text { online travel } \\
\text { agent }(\%)\end{array}$ & $\begin{array}{l}\text { Group 2: } \\
\text { use online } \\
\text { travel agent }(\%)\end{array}$ & \\
\hline American Airlines & Delta & 18.8 & 33.0 & 1.8 \\
\hline American Airlines & JetBlue & 7.0 & 20.2 & 2.9 \\
\hline American Airlines & Southwest & 20.6 & 36.3 & 1.8 \\
\hline American Airlines & Spirit & 5.6 & 8.5 & 1.5 \\
\hline American Airlines & US Airways & 17.5 & 24.9 & 1.4 \\
\hline Delta & American Airlines & 16.5 & 30.9 & 1.9 \\
\hline Delta & JetBlue & 6.9 & 19.4 & 2.8 \\
\hline Delta & Southwest & 21.3 & 34.4 & 1.6 \\
\hline Delta & Spirit & 2.9 & 7.4 & 2.6 \\
\hline Delta & US Airways & 9.2 & 21.0 & 2.3 \\
\hline JetBlue & American Airlines & 14.0 & 37.7 & 2.7 \\
\hline JetBlue & Delta & 15.5 & 38.7 & 2.5 \\
\hline JetBlue & Southwest & 14.9 & 42.8 & 2.9 \\
\hline JetBlue & Spirit & 4.2 & 8.2 & 1.9 \\
\hline JetBlue & US Airways & 7.0 & 19.5 & 2.8 \\
\hline Southwest & American Airlines & 11.3 & 24.3 & 2.2 \\
\hline Southwest & Delta & 13.3 & 24.6 & 1.8 \\
\hline Southwest & JetBlue & 4.1 & 15.3 & 3.8 \\
\hline Southwest & Spirit & 3.9 & 8.5 & 2.2 \\
\hline Southwest & US Airways & 6.5 & 17.6 & 2.7 \\
\hline Spirit & American Airlines & 21.1 & 30.4 & 1.4 \\
\hline Spirit & Delta & 12.1 & 28.3 & 2.3 \\
\hline Spirit & JetBlue & 7.9 & 15.6 & 2.0 \\
\hline Spirit & Southwest & 26.3 & 45.2 & 1.7 \\
\hline Spirit & US Airways & 3.8 & 19.2 & 5.1 \\
\hline US Airways & American Airlines & 31.7 & 40.3 & 1.3 \\
\hline US Airways & Delta & 18.8 & 37.9 & 2.0 \\
\hline US Airways & JetBlue & 6.3 & 16.9 & 2.7 \\
\hline US Airways & Southwest & 21.3 & 42.7 & 2.0 \\
\hline US Airways & Spirit & 1.8 & 8.7 & 4.8 \\
\hline
\end{tabular}

The managerial implications of our results for airlines is that it is vital for airline companies to continue to build awareness of their brands and their services through offline and online advertising so that customers include them in their consideration sets. The OTAs and meta-search engines are powerful partners because they promote the airlines and airlines must therefore work with these online marketing partners whilst also attempting to maintain their direct relationships with customers. 
Airlines should exploit their historical advantages from their loyalty schemes and knowledge of frequent flyers to encourage direct search. Comparison websites should continue to build incentives for customers to search with them, e.g. better prices and different services.

The results for the generic search patterns reported in Table 7 demonstrate the high level of usage of comparison websites, which have advanced, multi-criteria search functionality across airlines. However, this doesn't give any information about the effects of the comparison website on primary search patterns. The generic search pattern results mean that the population of users that look at airline websites can be divided into two groups, those that don't use online travel agents, and those that do use online travel agents. The more detailed analysis of these two groups shown in Table 8 demonstrates conclusively that the online travel agent acts as a catalyst to increase the level of primary search. That is, the use of comparison websites stimulates primary search with airline websites rather than acting as a substitute for primary search. Relating this result to the online consideration set results shown in Table 6, an important corollary of these results is that if users of comparison websites are more likely to conduct additional research with a second airline, then the average online consideration set of model 1 searchers (those that only use airline websites) must be lower than that of model 3 searchers (those that use both comparison websites and conduct primary research). The average online consideration sets reported in Table 6 is based on the union of model 1 and model 3 searchers. Model 1 searchers must therefore have an average online consideration set lower than 2.58. The logic is that if comparison websites increase the likelihood of additional search, then model 3 users will visit more airline websites than model 1 (non-comparison website) users. The figure of 2.58 for Germany is based on all users that visit airline websites, i.e. model 1 and model 3 users. This means that model 1 users must have a lower online consideration set than model 3 users. The research issue regarding small online consideration sets remains an important question that cannot be explained by the use of comparison websites.

The sample in our research is of the order of magnitude of one million in the United States, and 100,000 online users in Germany. These samples are two to three orders of magnitude larger than traditional research samples in academic surveys, where a very large survey would be around one thousand. In total 42 natural experiments were conducted and reported in Tables 8 and 9. In addition, a further 24 natural experiments were conducted with Opodo in Germany (8), and Kayak in both Germany (8) and the US (8).

The differences between OTA users and non-OTA users are measured in multiples of between 1.4 and 10, i.e. these are not small differences in probability between two samples of Group 1 and Group 2. In Germany, online users are on average four times as likely to visit a further airline website if they use online travel agents compared to those that do not use online travel agents (i.e. the average of column 5, Table 8), and in the US the figure is 2.38. Some possible explanations for the difference in the effect of the comparison website on direct search between the US and Germany are prior knowledge of the market and decision making style (Karimi et al. 2015) and industry concentration (Holland and Jacobs 2015). The results are consistent for every single airline pair tested, including the additional 
research with Opodo and Kayak. Statistical tests are therefore not applicable because at this level of sampling differences of this magnitude are real differences and cannot be attributed to large variances or sampling error. Nevertheless, a $t$ test was calculated for both countries. The results were consistent in the US and Germany $(p<.001)$ and confirm the statistical significance of the differences between the probabilities.

Notwithstanding the scale of the data sample, there are some limitations to the study. In order to be consistent with prior research into the concept of the consideration set, we excluded comparison website visits from the calculation of the consideration set. However, the high use of comparison websites suggests that search in the airline market is more extensive than the consideration set suggests, at least for Model 2 and Model 3 searchers.

Secondly, we make the distinction between individuals visiting only one airline website, which we define as conducting e-service, and those who are visiting two or more airline websites, which are defined as searchers. The assumption is that customers who are actively searching for flight information visit more than one airline website, and that those who visit just one airline are most likely to be conducting some form of e-service. There are two possible errors here: (1) e-service users are actually searching but only visit one airline; (2) someone may be conducting e-service on two or more airline websites. The scale of these errors though is likely to be small because the assumptions are plausible and consistent with prior literature on the consideration set. Note that if we include all of the online visits to just one website as searchers, then this would reduce the size of the online consideration set considerably, which is stronger support for hypothesis 1 .

Furthermore, we are aware that search for scheduled flight services has distinct characteristics when compared to other product categories. For many travellers, the availability of flights has a significant influence on the purchasing decision. Gaining transparency over available flights is therefore often the first step, which then can be followed with more detailed search on the airline websites. The mapping out of the actual customer journey is a subject for future research. The small online consideration sets may be partly explained by the familiarity of customers with specific routes and possibly also limited options, and the propensity to fly with one airline to take advantage of loyalty programs. A further explanation might be the existence of airline alliances on which single brand websites such as American Airline contain other partner brands and flight options, which enable the customer to consider other flight options without needing to visit other airline websites.

\section{Conclusions}

The methodology developed in this research illustrates a novel use of online panel data to explore more detailed aspects of search behaviour, in particular the interaction effects between different types of websites, in this case comparison websites and airline websites. The use of set theory to analyse audience duplication reports is a novel methodology to create and analyse Venn diagrams of overlapping search behaviour between groups of websites. This approach made it possible to 
measure the high level generic search patterns that are shown in Fig. 1, and also provided a mechanism to analyse model 1 and model 3 searchers in more detail.

The marketing concept of the consideration set was applied in an online context and operationalized using airline websites only, i.e. primary research. The results of 2.58 in Germany and 2.74 are consistent with earlier studies. The average online consideration set can be expanded to estimate the distribution of searchers which shows that very few consumers, only $14 \%$ of the total, look at four or more websites. This raises the question about why $86 \%$ of consumers only look at 2 or 3 airline websites rather than follow a rational, extensive search strategy.

The most obvious explanation for the small online consideration set is that comparison engines have extensive search and comparison functionality and that this is used as a substitute for extensive primary search. To an extent this is true because a high proportion of online users in both markets use an OTA or metasearch engine. However, the propensity to conduct more direct research is significantly higher for those users that include an OTA or meta-search engine in their search process than those users that do not and only look at the airline websites. The conclusion therefore is that comparison websites are a catalyst for further direct research, rather than a substitute for direct search with individual airline websites.

In a more general sense, the empirical evidence reported here does not support the rational consumer model, where one would expect consumers to either conduct extensive primary search with the airline websites, or use a combination of airline and comparison websites. An explanation for the apparently irrational behaviour of consumers in their search for airline tickets must therefore be found elsewhere. Bounded rationality (Simon 1955), brand loyalty (Jacoby and Kyner 1973), lack of perceived competition in pricing and flight choice and repeat buying behaviour are all rich areas for future research.

Acknowledgments This research is supported by the Fonds National de la Recherche, Luxembourg (7842603). The authors would like to acknowledge comScore for providing the research data for this paper. Please see http://www.comscore.com/About-comScore for further information about comScore. The authors have conducted the analysis and interpretation of the data, and any errors in the paper are the sole responsibility of the authors.

Open Access This article is distributed under the terms of the Creative Commons Attribution 4.0 International License (http://creativecommons.org/licenses/by/4.0/), which permits unrestricted use, distribution, and reproduction in any medium, provided you give appropriate credit to the original author(s) and the source, provide a link to the Creative Commons license, and indicate if changes were made.

\section{References}

Anderson C (2011) Search, OTAs, and online booking: an expanded analysis of the billboard effect. Cornell Hosp Rep 11(8):4-10

Bakos Y (1998) The emerging role of electronic marketplaces on the Internet. Commun ACM 41(8):35-42 
Baye MR, Morgan J, Scholten P (2003) The value of information in an online consumer electronics market. J Public Policy Mark 22(1):17-25

Bilotkach V (2010) Reputation, search cost, and airfares. J Air Transport Manag 16(5):251-257

Breuer R, Brettel M, Engelen A (2011) Incorporating long-term effects in determining the effectiveness of different types of online advertising. Mark Lett 22(4):327-340

Brown JJ, Wildt AR (1992) Consideration set measurement. J Acad Mark Sci 20(3):235-243

Bucklin RE, Sismeiro C (2009) Click here for Internet insight: advances in clickstream data analysis in marketing. J Interact Mark 23(1):35-48

Buhalis D, Licata MC (2002) The future etourism intermediaries. Tour Manag 23(3):207-220

Campbell DT, Stanley JC (1963) Experimental and quasi-experimental designs for research on teaching. In: Gage NL (ed) Handbook of research on teaching. Rand McNally, Chicago

Chatterjee P, Wang Y (2012) Online comparison shopping behavior of travel consumers. J Qual Assur Hosp Tour 13(1):1-23

Chen Y, Wang Q, Xie J (2011) Online social interactions: a natural experiment on word of mouth versus observational learning. J Mark Res 48(2):238-254

Christodoulidou N, Connolly DJ, Brewer P (2010) An examination of the transactional relationship between online travel agencies, travel meta sites, and suppliers. Int J Contemp Hosp Manag 22(7):1048-1062

Chung S (2013) The role of online infomediaries for consumers: a dual perspective about price comparison and information mediation. Internet Res 23(3):338-354

Collins AT, Rose JM, Hess S (2010) Search based internet surveys: airline stated choice. Working paper ITLS-WP-10-01, ITLS Sydney and ITS Leeds, pp 1-15

ComScore (2014) ComScore Unified Digital Measurement ${ }^{\mathrm{TM}}$ Methodology. ComScore. http://www. comscore.com/Media/Files/Misc/comScore_Unified_Digital_Measurement_Methodology_PDF. Accessed 1 Aug 2014

Dickinger A, Stangl B (2012) Online information search: differences between goal-directed and experiential search. J Inf Technol Tour 13(3):239-257

Expedia (2015) Annual report 2015. Expedia Inc. http://www.sec.gov/Archives/edgar/data/1324424/ 000119312515035706/d838066d10k.htm. Accessed 27 Aug 2015

Hauser JR, Wernerfelt B (1990) An evaluation cost model of consideration sets. J Consum Res 16(4):393-408

Hauser JR, Roberts JH, Urban GL (1983) Forecasting sales of a new consumer durable. In: Zufryden FS (ed) Advances and practices in marketing science. The Institute of Management Science, Providence, pp 115-128

Holland CP, Jacobs JA (2015) The influence of the Herfindahl-Hirschman Index and product complexity on search behaviour: a cross-sector study of the U.S., Germany and U.K. In: Proceedings of the European Conference on Information Systems (ECIS 2015), paper 80, 25th-28th May, Münster, Germany

Holland CP, Mandry GD (2013) Online search and buying behaviour in consumer markets. In: 46th Hawaii international conference on system sciences. IEEE, Maui, Hawaii, pp 2918-2927

Howard JA (1963) Marketing management: analysis and planning, revised ed. Richard D. Irwin, Homewood

Howard JA (1977) Consumer Behavior: Application of Theory. McGraw-Hill, New York

Howard JA, Sheth JN (1969) The theory of buyer behavior. Wiley, New York

Inkpen G (1998) Information technology for travel and tourism, 2nd edn. Longman, Harlow

Jacoby J, Kyner DB (1973) Brand loyalty vs. repeat purchasing behavior. J Mark Res 10(1):1-9

Janger J (2010) Determinants of price comparison and supplier switching rates in selected sectors. Monet Policy Econ 1(10):66-86

Jepsen AL (2007) Factors affecting consumer use of the internet for information search. J Interact Mark 21(3):21-34

Johnson EJ, Moe WW, Fader PS, Bellman S, Lohse GL (2004) On the depth and dynamics of online search behavior. Manag Sci 50(3):299-308

Jung K, Cho YC, Lee S (2014) Online shoppers' response to price comparison sites. J Bus Res 67(10):2079-2087

Kamakura WA, Moon S (2009) Quality-adjusted price comparison of non-homogeneous products across internet retailers. Int J Res Mark 26(3):189-196 
Karimi S, Papamichail KN, Holland CP (2015) The effect of prior knowledge and decision-making style on the online purchase decision-making process: a typology of consumer shopping behaviour. Decis Support Syst 77:137-147

Kracht J, Wang Y (2010) Examining the tourism distribution channel: evolution and transformation. Int J Contemp Hosp Manag 22(5):736-757

Laffey D, Gandy A (2009) Comparison websites in UK retail financial services. J Financ Serv Mark 14(2):173-186

Law R, Guillet BD, Leung R (2010) An analysis of the lowest fares and shortest durations for air-tickets on travel agency websites. J Travel Tour Mark 27(6):635-644

Lee J, Soutar G, Daly T (2007) Tourists' search for different types of information: a cross-national study. J Inf Technol Tour 9(3/4):165-176

Lohse GL, Bellman S, Johnson EJ (2000) Consumer buying behavior on the Internet: findings from panel data. J Interact Mark 14(1):15-29

McDonald S, Wren C (2012) Informative brand advertising and pricing strategies in internet markets with heterogeneous consumer search. Int J Econ Bus 19(1):103-117

McLeod SA (2012) Experimental method, SimplyPsychology. http://www.simplypsychology.org/ experimental-method.html. Accessed 16 Jan 2015

Meyer BD (1995) Natural and quasi-experiments in economics. J Bus Econ Stat 13(2):151-161

Meyer T, Stobbe A (2010) Majority of bank customers in Germany do research online: findings of a clickstream analysis. Digit Econ Struct Change 79:1-32

Neslin SA, Shoemaker RW (1983) Using a natural experiment to estimate price elasticity: the 1974 sugar shortage and the ready-to-eat cereal market. J Mark 47(1):44-57

Pearce B (2014) The shape of air travel markets over the next 20 years. International Air Transport Association (IATA), November. http://www.iata.org/whatwedo/Documents/economics/ 20yearsForecast-GAD2014-Athens-Nov2014-BP.pdf. Accessed 27 Aug 2015

Priceline (2015) Annual report 2014. Edgar online. http://ir.pricelinegroup.com/secfiling.cfm?filingID= 1075531-15-7\&CIK=1075531. Accessed 27 Aug 2015

Roberts J (1989) A grounded model of consideration set size and composition. In: Srull TK (ed) NAadvances in consumer research, 16. Association for Consumer Research, Provo, pp 749-757

Robertshaw G (2011) An examination of the profitability of customers acquired through price comparison sites: implications for the UK insurance industry. J Direct Data Digit Mark Pract 12(3):216-229

Shocker AD, Ben-Akiva M, Boccara B, Nedungadi P (1991) Consideration set influences on consumer decision-making and choice: issues, models, and suggestions. Mark Lett 2(3):181-197

Simon HA (1955) A behavioral model of rational choice. Q J Econ 69(1):99-118

Stigler GJ (1961) The economics of information. J Polit Econ 69(3):213-225

Tan CH, Goh KY, Teo HH (2010) Effects of comparison shopping websites on market performance: does market structure matter? J Electron Commer Res 11(3):193-219

Werthner H, Klein S (1999) Information technology and tourism-a challenging relationship. Springer, Vienna

Xiang Z, Gretzel U (2010) Role of social media in online travel information search. Tour Manag 31(2):179-188

Xiang Z, Magnini VP, Fesenmaier DR (2015) Information technology and consumer behavior in travel and tourism: insights from travel planning using the internet. J Retail Consum Serv 22:244-249

Zhang J, Fang X, Liu Sheng OR (2006) Online consumer search depth: theories and new findings. J Manag Info Syst 23(3):71-95 